Jurnal Keperawatan Silampari

Volume 4, Nomor 1, Desember 2020

e-ISSN: 2581-1975

p-ISSN: 2597-7482

DOI: https://doi.org/10.31539/jks.v4i1.1515

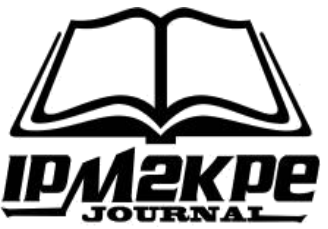

\title{
PENINGKATAN SELF EFFICACY REMAJA BERISIKO MENGGUNAKAN TERAPI PSIKOEDUKASI DENGAN MUSIK
}

\author{
Tasman $^{1}$, Heppi Sasmita ${ }^{2}$, Yessi Fadriyanti ${ }^{3}$, \\ N. Rachmadanur ${ }^{4}$, Lola Felnanda Amri ${ }^{5}$ \\ Politeknik Kesehatan Kementerian Kesehatan Padang ${ }^{1,2,3,4,5}$ \\ tasman868@gmail.com ${ }^{1}$
}

\begin{abstract}
ABSTRAK
Tujuan dari penelitian ini adalah untuk mengetahui peningkatan self efficacy remaja berisiko melalui kombinasi terapi psikoedukasi dengan musik di SMPN Kota Padang. Metode penelitian yang digunakan dalam penelitian ini adalah penelitian kuantitatif dengan desain penelitian quasi experimental pre-post test control group. Hasil penelitian menunjukkan bahwa rata-rata score self efficacy sebelum intervensi pada kelompok intervensi lebih rendah dari kelompok kontrol, namun sesudah intervensi diberikan kepada remaja menunjukkan adanya pengaruh terapi psikoedukasi dengan musik terhadap perubahan self efficacy siswa berisiko. Hasil uji statistik didapatkan P-value <0,05. Simpulan, ada peningkatan yang bermakna antara self efficacy sebelum dan sesudah intervensi terapi psikoedukasi dengan musik.
\end{abstract}

Kata Kunci: Psikoedukasi, Remaja, Self Efficacy

\begin{abstract}
The purpose of this study was to determine the increase in self-efficacy of adolescents at risk through a combination of psychoeducation therapy with music at SMPN Kota Padang. The research method used in this research is quantitative research with a quasiexperimental research design pre-post test control group. The results showed that the mean score of self-efficacy before the intervention group intervention was lower than the control group. Still, after the intervention was given to adolescents, it showed psychoeducation therapy with music on changes in student self-efficacy at risk. The statistical test results obtained a P-value <0.05. In conclusion, there is a significant increase in self-efficacy before and after psychoeducation therapy intervention with music.
\end{abstract}

Keywords: Psychoeducation, Youth, Self Efficacy

\section{PENDAHULUAN}

Masalah psikososial yang muncul pada remaja yang menunjukkan perilaku berisiko adalah penggunaan zat adiptif, kenakalan, perilaku seksual berisiko, dan menciderai diri sendiri diantaranya para remaja yang menjadi korban akibat terlibat kekerasan interpersonal. Kusumaryani (2017) menjelaskan bahwa remaja juga berisiko terhadap psikososialnya seperti pengangguran, perilaku agresif dan kriminalitas. Hal ini mengakibatkan remaja tersebut dapat terjerumus dan melakukan penyebab kenakalan remaja. 
Angka kejadian kenakalan remaja semakin lama semakin meningkat. Menurut Mendelson \& Tandon (2016) depresi merupakan gangguan kejiwaan yang paling umum dan salah satu penyebab morbiditas dan mortalitas di negara Amerika. Studi epidemiologis yang representatif secara nasional menunjukkan bahwa prevalensi depresi seumur hidup diantara remaja berusia 15 hingga 18 tahun adalah $11 \%$ dan 14\%, dengan perkiraan $20 \%$ remaja mengalami gangguan depresi berat pada saat mereka berusia 18 tahun.

Data KPAI (2016) mencatat anak korban Komisioner Bidang Pendidikan KPAI mengatakan, bahwa angka kasus tawuran hanya 12,9 persen, tapi tahun ini menjadi 14 persen. Sedangkan KPAI (2018) mencatat beberapa kasus antara lain kasus bidang pendidikan yaitu anak korban tawuran pelajar 54 orang, anak pelaku tawuran pelajar 74 orang, anak korban kekerasan di sekolah 129 orang, serta anak pelaku kekerasan di sekolah 116 orang. Disamping itu angka prevalensi penyalahgunaan narkoba paling tinggi yaitu di D.I Yogyakarta (6.6\%), diikuti DKI Jakarta (5.3\%) dan Sumatera Barat (4.7\%) (BNN, 2016). Sedangkan hasil penelitian Arsyam \& Murtiani (2017) menunjukkan bahwa lebih sebagian besar remaja mengalami depresi mulai dari depresi ringan sampai berat.

Depresi pada remaja ini terjadi sebagai akibat dari ketidakmampuan remaja dalam melakukan penyesuaian diri. Disamping itu dijelaskan bahwa penyesuaian diri sebagai usaha konformitas, menyiratkan bahwa individu seakan-akan mendapatkan tekanan kuat untuk harus selalu mampu menghindarkan diri dari penyimpangan perilaku baik moral, sosial dan emosional.

Proses kognitif akan menekan tuntutan atau tugas yang harus diselesaikan, kegagalan, serta kemunduran yang dapat berpengaruh terhadap perkembangan pribadi remaja. Individu dengan self esteem yang rendah cenderung kurang mampu berfikir secara analitik dalam mengungkapkan aspirasinya. Proses motivasi mengarahkan individu membentuk keyakinan tentang apa yang bisa dilakukan. Individu dengan self efficacy rendah tidak memiliki keyakinan mampu menetapkan tujuan dan membuat rencana tindakan yang dirancang mewujudkan tujuan.

Masalah low self efficacy apabila tidak segera diatasi akan berdampak terjadinya perilaku kekerasan baik pada diri sendiri maupun terhadap orang lain seperti bunuh diri. Oleh sebab itu sangat diperlukan peran dari perawat untuk menghindari dampak lanjut yang akan terjadi.Untuk mengatasi masalah perilaku berisiko ini pada remaja terutama masalah low self efficacy maka dapat diatasi dengan memberikan pendidikan kesehatan pada remaja dan bimbingan konseling yang dilakukan guru disekolah. Selain itu juga dapat diberikan beberapa terapi kepada remaja seperti Cognitive Therapy (CT), Behaviour Therapy (BT), Cognitive Behaviour Therapy (CBT), logotherapy, Terapi Kelompok Terapeutik (TKT) remaja, dan terapi psikoedukasi.

Kelompok psikoedukasi disebut juga sebagai sebagai kelompok pendidikan atau bimbingan, dari pada konseling atau terapi, menekankan penggunaan metode pendidikan untuk menyampaikan informasi dan mengembangkan keterampilan. Kelompok psikoedukasi bertujuan untuk mempromosikan pertumbuhan pribadi sesuai tahapan perkembangannya, pemberian informasi yang relevan, dan menyelesaikan masalah, atau konflik (Kesuma et al., 2018).

Kelompok psikoedukasi merupakan intervensi terapeutik yang menggabungkan psikoterapi dan pendidikan. Tujuan secara khusus, jenis kelompok ini sangat membantu dalam menyediakan ketrampilan dan bimbingan selama masa transisi, mengurangi 
kecemasan kemarahan, tekanan emosional lainya, memeperbaiki kemapuan interpersonal seperrti; memperkuat ketrampilan belajar (Kesuma et al., 2018).

Berdasarkan data dari media sosial bahwa banyak siswa di kota Padang yang melakukan tindakan menyakiti diri sendiri dengan aksi menyayat lengan sendiri. Hasil studi pendahuluan dengan wawancara dengan salah seorang guru dikota Padang didapatkan informasi bahwa tindakan menyayat lengan sendiri trend dikalangan remaja. Siswa yang melakukan tindakan tersebut termasuk anak yang pintar, dan alasan mereka melakukan pada umumnya ingin diperhatikan orang tua. Informasi dari anak yang melakukan tindakan melukai diri ini, mereka melakukan tindakan tersebut karena ingin diperhatikan orang tua, orang tua selama ini otoriter dan semua diatur orang tua. Anak tersebut mengatakan mereka harus mengikuti semua kemauan orang tua mereka seperti les ini, les itu tanpa peduli keinginan mereka. Disamping itu juga ada diantara siswa melakukan tindakan tersebut karena coba-coba mengikuti teman. Penjelasan dari kepala Dinas Pendidikan awalnya ditemui 1 (satu) orang anak yang melakukan tindakan tersebut yang diketahui melalui pemeriksaan handphone. Setelah penelusuran lebih lanjut ternyata ada kelompok mereka yang beranggotakan 6 orang, selanjutnya berkembang lagi menjadi 24 orang.

Survey awal yang dilakukan terhadap wakil kesiswaan disebuah SMP Kota Padang dan guru BK didapatkan informasi bahwa ada sekitar 110 siswa yang bermasalah. 55 orang diantaranya bermasalah karena tindakan asusila, kekerasan remaja, menghisap lem dan melukai diri sendiri. Wawancara dengan 6 orang siswa, pada umumnya alasan mereka bermasalah tersebut karena takut tidak diterima dan dikucilkan oleh temantemannya. Disamping itu alasan mereka juga karena ingin mendapatkan perhatian dari orang tuanya.

Upaya yang sudah dilakukan pihak sekolah adalah dengan memberikan arahan kepada siswa dan memanggil orang tua untuk penyelesaian masalah. Belum pernah dilakukan kombinasi terapi psikoedukasi dengan musik melalui media sosial untuk mengatasi masalah harga diri siswa tersebut.

\section{METODE PENELITIAN}

Desain yang digunakan dalam penelitian ini adalah quasi experimental pre-post test control group intervensi terapi psikoedukasi dengan musik yang mengelompokkan remaja menjadi dua kelompok yaitu yang diberi terapi psikoedukasi dengan musik dan yang tidak diberi terapi psikoedukasi dengan musik. Populasi dari penelitian ini 110 orang remaja dengan sampel 64 orang remaja. Pengambilan sampel dengan menggunakan proporsional random sampling.

Instrumen yang digunakan dalam penelitian ini adalah berupa kuesioner $\mathrm{A}, \mathrm{B}$, dan C dimana (A: Karakteristik responden, B: kuesioner untuk mengukur general self efficacy (GSE), dan C:Rosenberg Self Esteem Scale dengan menggunakan skala likert (1-4), dengan rentang nilai 10-40. Data diolah secara komputerisasi, dengan Analisa Bivariat dengan menggunakan uji $t$ dengan tingkat kepercayaan 95\% $(\alpha \leq 0,05)$. Hipotesis ditolak bila nilai $\mathrm{p} \leq 0,05)$ yakni terdapat peningkatan self efficacy setelah dilakukan terapi psikoedukasi dengan musik baik pada kelompok intervensi maupun kelompok kontrol. 
HASIL PENELITIAN

Analisis Univariat

Gambaran Karakteristik Siswa

Tabel. 1

Gambaran Usia

\begin{tabular}{lllllll}
\hline Variabel & Kelompok & Mean & SD & Median & Min - Mak & 95\% CI \\
\hline Usia & Intervensi & 14,30 & 0,61 & 14 & $13-16$ & $14,06-15,54$ \\
& Kontrol & 14,30 & 0,67 & 14 & $13-16$ & $14,03-14,56$ \\
\hline
\end{tabular}

Berdasarkan tabel 1 menunjukan rata-rata usia siswa berisiko pada kelompok intervensi adalah 14,30 dengan standar deviasi 0,61. Rata-rata usia siswa berisiko kelompok intervensi adalah diantara 14,06 sampai dengan 15,54. Rata-rata usia korban bencana gempa kelompok kontrol adalah 14,30 dengan standar deviasi 0,67.

Tabel. 2

Jenis Kelamin

\begin{tabular}{lcccc}
\hline Karakteristik & \multicolumn{2}{c}{ Intervensi } & \multicolumn{3}{c}{ Kontrol } \\
\cline { 2 - 5 } & $\mathrm{N}$ & $\%$ & $\mathrm{~N}$ & $\%$ \\
\hline Jenis Kelamin & & & & \\
Laki-laki & 9 & 33,3 & 14 & 51,9 \\
Perempuan & 18 & 66,7 & 13 & 48,1 \\
\hline Jumlah & 27 & 100 & 27 & 100 \\
\hline
\end{tabular}

Berdasarkan tabel 2 menunjukan terhadap 27 siswa berisiko pada kelompok intervensi menunjukkan bahwa proporsi terbesar jenis kelamin siswa berisiko adalah perempuan $(66,7 \%)$, dan pada kelompok kontrol menunjukkan mayoritas adalah laki-laki $(51,9 \%)$.

\section{Gambaran Self Efficacy Siswa Berisiko Sebelum Terapi Psikoedukasi dengan Musik pada Kelompok Intervensi dan Kontrol}

Tabel. 3

Analisis Self efficacy Sebelum Mengikuti Terapi Psikoedukasi dengan Musik pada Kelompok Intervensi dan Kelompok Kontrol

\begin{tabular}{|c|c|c|c|c|c|c|c|}
\hline Variabel & $\begin{array}{l}\text { Jenis } \\
\text { Kelompok }\end{array}$ & Mean & Median & $\mathrm{SD}$ & $\begin{array}{l}\text { Min - } \\
\text { Max }\end{array}$ & $95 \% \mathrm{CI}$ & $\begin{array}{l}\text { Shapiro- } \\
\text { Wilk }\end{array}$ \\
\hline \multirow[t]{2}{*}{ Self efficacy } & Intervensi & 25,11 & 25 & 2,69 & $20-29$ & $24,05-26,18$ & 0,144 \\
\hline & Kontrol & 25,44 & 26 & 3,4 & $15-29$ & $24,10-26,79$ & 0,002 \\
\hline
\end{tabular}

Berdasarkan tabel 3 menunjukan self efficacy pada siswa berisiko pada kelompok intervensi sebelum dilakukan intervensi penelitian adalah 25,11. Sedangkan self efficacy pada kelompok kontrol sebelum dilakukan intervensi penelitian adalah 25,44. Hasil ini menunjukkan bahwa self efficacy sebelum intervensi pada kelompok intervensi lebih rendah dari kelompok kontrol. Hasil uji Shapiro-Wilk menunjukkan distribusi self efficacy siswa berisiko kelompok intervensi berbentuk normal, dimana pada kelompok intervensi ( $\mathrm{p}$ value $>0,05)$ dan kelompok kontrol berbentuk tidak normal ( $\mathrm{p}$ value $<0,05)$. 


\section{Gambaran Self Efficacy Siswa Berisiko Sesudah Terapi Psikoedukasi dengan Musik pada Kelompok Intervensi dan Kontrol}

Tabel. 4

Analisis Self efficacy Sesudah Mengikuti Terapi Psikoedukasi dengan Musik pada Kelompok Intervensi dan Kelompok Kontrol

\begin{tabular}{llcccccc}
\hline Variabel & Jenis & Mean & Median & SD & $\begin{array}{c}\text { Min - } \\
\text { Kax }\end{array}$ & $95 \%$ CI & $\begin{array}{c}\text { Shapiro- } \\
\text { Wilk }\end{array}$ \\
\hline Self & Intervensi & 31,22 & 31 & 3,4 & $24-37$ & $29,88-32,57$ & 0,463 \\
efficacy & Kontrol & 26,70 & 27 & 3,64 & $19-38$ & $25,27-28,14$ & 0,004 \\
\hline
\end{tabular}

Berdasarkan tabel 4 menunjukan tanda dan gejala PTSD, didapatkan self efficacy pada kelompok intervensi sesudah dilakukan intervensi penelitian adalah 31,22 dengan standar deviasi 3,4. Sedangkan rata-rata self efficacy pada kelompok kontrol sesudah dilakukan intervensi penelitian adalah 26,70 dengan standar deviasi 3,64. Hasil ini menunjukkan bahwa rata-rata self efficacy sesudah intervensi pada kelompok intervensi lebih tinggi dari kelompok kontrol.

\section{Analisis Bivariat}

\section{Perubahan Self Efficacy Siswa Berisiko Sebelum dan Sesudah Terapi Psikoedukasi} dengan Musik pada Kelompok Intervensi dan Kontrol

Tabel. 5

Analisis Peningkatan Self efficacy pada Siswa Berisiko Sebelum - Sesudah Terapi Psikoedukasi dengan Musik Pada Kelompok Intervensi dan Kelompok Kontrol

\begin{tabular}{llllllcc}
\hline No & Variabel & Kelompok & N & Mean & SD & t & P value \\
\hline \multirow{2}{*}{1} & Self efficacy & & & & & & \\
& a. Sebelum & Intervensi & 27 & 25,11 & 2,69 & $-8,069$ & 0,000 \\
& b. Sesudah & & 27 & 31,22 & 3,40 & & \\
\hline 2 & Self efficacy & & & & & & \\
& a. Sebelum & Kontrol & 27 & 25,44 & 3,40 & $-1,839$ & 0,077 \\
& b. Sesudah & & 27 & 26,70 & 3,64 & & \\
\hline
\end{tabular}

Berdasarkan tabel 5 menunjukan rata-rata self efficacy siswa berisiko pada kelompok intervensi sebelum psikoedukasi dengan musik adalah 25,11 dengan standar deviasi 2,69. Pengukuran sesudah psikoedukasi dengan musik didapat rata-rata self efficacy siswa berisiko adalah 31,22 dengan standar deviasi 3,40. Terlihat rata-rata peningkatan antara self efficacy siswa berisiko sebelum dan sesudah intervensi pada kelompok intervensi adalah sebesar 6,11. Hasil uji statistik didapatkan nilai $\mathrm{P}<0,05$, maka dapat disimpulkan ada peningkatan yang bermakna antara self efficacy siswa berisiko sebelum dan sesudah intervensi psikoedukasi dengan musik pada kelompok intervensi.

Rata-rata self efficacy siswa berisiko pada kelompok kontrol sebelum psikoedukasi dengan musik adalah 25,44 dengan standar deviasi 3,40. Pengukuran sesudah psikoedukasi dengan musik didapat rata-rata self efficacy siswa berisiko adalah 26,70 dengan standar deviasi 3,64. Terlihat rata-rata peningkatan antara self efficacy siswa berisiko sebelum dan sesudah intervensi pada kelompok intervensi adalah sebesar 1,26. Hasil uji statistik didapatkan nilai $\mathrm{P}>0,05$, maka dapat disimpulkan tidak ada peningkatan yang bermakna antara self efficacy siswa berisiko sebelum dan sesudah intervensi psikoedukasi dengan musik pada kelompok kontrol. 


\section{Perbedaan Self Efficacy Siswa Berisiko yang Mendapatkan Terapi Psikoedukasi dengan Musik dengan yang Tidak Mendapatkan Terapi Psikoedukasi dengan Musik}

Tabel. 6

Analisis Peningkatan Self efficacy Kelompok Intervensi dan Kontrol Sebelum dan Sesudah Terapi Psikoedukasi dengan Musik

\begin{tabular}{|c|c|c|c|c|c|c|c|}
\hline No & Kelompok & Variabel & Mean & SD & $\mathrm{N}$ & $\mathrm{t}$ & $P$ value \\
\hline \multirow{2}{*}{1} & Intervensi & \multirow{2}{*}{$\begin{array}{c}\text { Self Efficacy Sebelum } \\
\text { Intervensi }\end{array}$} & 25,44 & 3,40 & 27 & \multirow{2}{*}{$-3,99$} & \multirow{2}{*}{0,691} \\
\hline & Kontrol & & 25,11 & 2,69 & 27 & & \\
\hline 2 & Intervensi & \multirow{2}{*}{$\begin{array}{l}\text { Self efficacy sesudah } \\
\text { intervensi }\end{array}$} & 26,70 & 3,64 & 27 & \multirow{2}{*}{4,717} & \multirow{2}{*}{0,000} \\
\hline & Kontrol & & 31,22 & 3,40 & 27 & & \\
\hline
\end{tabular}

Berdasarkan tabel 6 menunjukan rata-rata self efficacy siswa berisiko antara kelompok intervensi dan kelompok kontrol berbeda sebesar 0,33 sebelum psikoedukasi dengan musik. Hasil uji statistik menunjukkan bahwa tidak terjadi penurunan bermakna self efficacy siswa berisiko antara kelompok intervensi dengan kelompok kontrol sebelum psikoedukasi dengan musik (P value $>0,05$ ). Rata-rata self efficacy siswa berisiko pada kelompok intervensi lebih rendah 4,52 dibandingkan kelompok kontrol setelah psikoedukasi dengan musik. Hasil uji statistik didapatkan nilai $\mathrm{P}<0,05$, artinya self efficacy siswa berisiko kelompok intervensi meningkat secara bermakna dari kelompok kontrol.

\section{PEMBAHASAN}

\section{Gambaran Karakteristik Siswa}

Rata-rata usia siswa berisiko kelompok intervensi adalah diantara 14,06 sampai dengan 15,54. Rata-rata usia siswa berisiko kelompok kontrol adalah diantara 14,03 sampai dengan 14,56. Hasil penelitian terhadap 27 siswa berisiko pada kelompok intervensi menunjukkan bahwa lebih separo jenis kelamin siswa berisiko adalah perempuan $(66,7 \%)$, sedangkan pada kelompok kontrol menunjukkan bahwa karakteristik jenis kelamin remaja berisiko dengan proporsi terbesar adalah laki-laki(51,9\%).

Persiapan yang matang sedini mungkin terhadap perencanaan karier, efikasi diri pengambilan keputusan karier, serta adaptabilitas karier perlu dilakukan. Persiapan karier seharusnya dimulai ketika individu menginjak usia 13-15 tahun, atau masuk pada kelompok masa remaja awal. Dimana individu yang sedang berkembang dengan memiliki minat serta pilihan orentasi karier yang relatif sudah jelas (Kesuma et al., 2018).

\section{Perubahan Self Efficacy Siswa Berisiko Sebelum dan Sesudah Terapi Psikoedukasi dengan Musik pada Kelompok Intervensi dan Kontrol}

Hasil penelitian menunjukkan bahwa rata-rata score self efficacy sebelum intervensi pada kelompok intervensi lebih rendah dari kelompok kontrol. Self efficacy berhubungan dengan keyakinan seseorang terhadap kemampuannya dalam melakukan sesuatu atau halhal yang berbeda dibawah kondisi tertentu. Adapun individu yang memiliki self efficacy tinggi akan membantu menciptakan perasaan tenang dalam menghadapi tugas akademik maupun kondisi yang sulit. 
Individu yang self efficacynya rendah cenderung menghindari situasi-situasi yang diyakini melampaui kemampuan yang dimiliki. Self efficacy rendah mengarahkan individu untuk menghindari lingkungan dan kegiatan serta memperlambat perkembangan potensi.

Individu dengan self efficacy rendah tidak memiliki keyakinan mampu menetapkan tujuan dan membuat rencana tindakan yang dirancang mewujudkan tujuan. Proses afektif dimana remaja yang memiliki self efficacy rendah tidak yakin dengan potensi yang dimiliki dan berpersepsi lingkungannya berbahaya dan dapat mengancam dirinya serta tidak mampu mengatasi ancaman tersebut.

Hasil analisis self efficacy pada siswa berisiko sebelum dan sesudah intervensi pada kelompok intervensi menunjukkan bahwa ada pengaruh terapi psikoedukasi dengan musik terhadap perubahan self efficacy siswa berisiko. Hasil uji statistik didapatkan nilai $\mathrm{P}<0,05$, maka dapat disimpulkan ada peningkatan yang bermakna antara self efficacy sebelum dan sesudah intervensi terapi psikoedukasi dengan musik.

Hasil penelitian hampir sama dengan hasil penelitian yang dilakukan Situmorang tahun 2017 dan 2018 yang hasil penelitiannya menunjukkan bahwa konseling kelompok dengan pendekatan terapi perilaku kognitif menggunakan teknik terapi musik pasif secara signifikan efektif untuk meningkatkan efikasi diri mahasiswa (Situmorang, 2017a; Situmorang, 2018).

Penelitian yang dilakukan Situmorang pada tahun 2017 dan 2018 menjelaskan bahwa music therapy yang diberikan merupakan salah satu teknik dalam memberikan layanan intervensi untuk membantu mahasiswa meningkatkan self-efficacy sehingga akan jauh lebih efektif dibandingkan dengan layanan intervensi konseling konvensional yang dilakukan. Disamping itu dijelaskan bahwa dengan music therapy, mahasiswa dapat mereduksi kecemasannya terhadap skripsi dan meningkatkan rasa percaya diri dalam menyelesaikan skripsi (Situmorang, 2017b; Situmorang et al., 2018).

Psikoedukasi yang diberikan melalui musik akan membuat remaja semaakin mudah memahami apa yang akan disampaikan. Situmorang (2018) menjelaskan bahwa penggunaan musik saat melakukan konseling dapat meningkatkan produksi keempat hormon positif yang ada di dalam tubuh manusia, yaitu endorphin, dopamine, serotonin, dan oxytocin. Fungsi hormon positif tersebut akan dapat membuat tubuh lebih terasa rileks, mampu mereduksi kecemasan atau stres, dapat meningkatkan kebahagiaan, meningkatkan kecerdasan, dan juga dapat meningkatkan rasa percaya diri. Individu dengan self efficacy rendah tidak memiliki keyakinan mampu menetapkan tujuan dan membuat rencana tindakan yang dirancang mewujudkan tujuan. Proses afektif dimana remaja yang memiliki self efficacy rendah tidak yakin dengan potensi yang dimiliki dan berpersepsi lingkungannya berbahaya dan dapat mengancam dirinya serta tidak mampu mengatasi ancaman tersebut.

Hasil analisis self efficacy pada siswa berisiko sebelum dan sesudah intervensi pada kelompok kontrol menunjukkan bahwa tidak ada perbedaan antara self efficacy saat pre test dengan post test pada kelompok kontrol. Tidak ada perbedaan antara self efficacy siswa berisiko pada kelompok kontrol sebelum dan sesudah dilakukan psikoedukasi melalui musik yang diberikan melalui mesia sosial disebabkan karena pada kelompok kontrol hanya diberikan pendidikan kesehatan remaja secara umum tentang masalah yang dialami remaja dan penjelasan tentang upaya mengatasi, namun tidak dilatih khusus. Dengan belajar tentang masalah dan upaya mengatasi masalah tersebut serta strategi mengatasi stress akibat persoalan remaja akan memudahkan individu dalam pengelolaan rasa percaya dirinya. 
Menurut Nogaj (2020) musik klasik yang slow mempunyai fungsi menenangkan pikiran dan katarsis emosi, serta dapat mengoptimalkan tempo, ritme, melodi dan harmoni yang teratur sehingga menghasilkan gelombang alfa serat gelombang tetha dalam gendang telinga sehingga memberikan efek menenangkan yang membuat otak siap menerima masukan baru, rileks, dan menidurkan, sehingga terapi music klasik (mozart) bisa digunakan pada anak yang mengalami gangguan emosional (Padila et al., 2020).

\section{Perbedaan Self Efficacy Siswa Berisiko yang Mendapatkan Terapi Psikoedukasi dengan Musik dengan yang Tidak Mendapatkan Terapi Psikoedukasi dengan Musik}

Rata-rata self efficacy siswa berisiko pada kelompok intervensi lebih rendah 4,52 dibandingkan kelompok kontrol setelah terapi psikoedukasi dengan musik. Hasil uji statistik didapatkan nilai Pvalue $<0,05$, artinya terdapat perbedaan bermakna self efficacy pada siswa berisiko kelompok intervensi dengan kelompok kontrol.

Psikoedukasi diberikan agar remaja memiliki pemahaman dan penerimaan terhadap masalah yang dihadapi termasuk masalah self efficacy. Psikoedukasi dapat digunakan dalam berbagai setting situasi seperti di sekolah. Metode atau cara pemberian edukasi bervariasi, tergantung pada siapa yang akan diedukasi, pada remaja dapat dilakukan melalui media sosial. Saling berbagi dan saling memberikan dukungan melalui media sosial akan meningkatkan rasa percaya diri remaja sehingga harga diri remaja juga akan meningkat.

Beberapa penelitian telah membuktikan efektifitas psikoedukasi dengan musik diantaranya Hasil penelitian psikoedukasi menunjukkan adanya perbedaan skor yang signifikan terhadap perlakuan tanpa psikoedukasi (prates) dan dengan perlakuan psikoedukasi (pascates). Hasil penelitian Kartikasari et al., (2017)menunjukkan terdapat perubahan bermakna self efficacy keluarga dengan sosial okupasi klien schizophrenia setelah diberikan terapi psikoedukasi $\mathrm{p}<0,05)$ dan terdapat perbedaan perubahan bermakna pada kelompok kontrol dan intervensi $(\mathrm{p}<0,05)$.

Hasil penelitian Kesuma et al., (2018) menunjukkan bahwa kelompok psikoedukasional dipandang mampu untuk memenuhi kebutuhan pendidik dalam meningkatkan efikasi diri pengambilan karier dan adaptabilitas karier peserta didik. Kelompok psikoedukasional menekankan penggunaan metode pendidikan untuk menyampaikan informasi dan mengembangkan keterampilan. Kelompok psikoedukasi bertujuan untuk mempromosikan pertumbuhan pribadi sesuai tahapan perkembangannya, pemberian informasi yang relevan, dan menyelesaikan masalah, atau konflik.

Kondisi di lapangan menunjukkan bahwa keterampilan efikasi diri dan adaptasi terhadap karier peserta didik masih cenderung rendah, hal ini dapat dipengaruhi oleh faktor internal (motivasi, tujuan, kepribadian, dsb) maupun eksternal (keluarga, teman sebaya, dsb). Semakin sering dan rutin seseorang yang mengalami mengikuti kegiatan cepat pemahaman tentang masalah yang dihadapi. Disamping itu energi positif yang didapatkan melalui pemberian informasi disaat psikoedukasi membuat individu menyadari pentingnya rasa percaya diri. Psikoedukasi melalui musik lebih membuat seseorang merasa tenang dan nyaman. 


\section{SIMPULAN}

Rata-rata score self efficacy sebelum intervensi pada kelompok intervensi lebih rendah dari kelompok kontrol. Ada pengaruh terapi psikoedukasi dengan musik terhadap perubahan self efficacy siswa berisiko. Ada peningkatan yang bermakna antara self efficacy sebelum dan sesudah intervensi terapi psikoedukasi dengan musik.

\section{SARAN}

Terkait dengan simpulan hasil penelitian, ada beberapa hal yang dapat disarankan demi keperluan pengembangan dari hasil penelitian efektifitas terapi psikoedukasi melalui musikterhadap upaya meningkatkan self efficacy remaja berisiko.

Perlu penelitian kualitatif untuk melengkapi informasi tentang sejauh mana terapi psikoedukasi melalui musikdapat menyelesaikan masalah self efficacy. Perlu perencanaan yang terarah dan berkesinambungan dalam meningkatkan kwalitas untuk penerapan terapi psikoedukasi melalui musiksehingga mendapatkan hasil yang lebih baik

Perlu dilakukan penyempurnaan pelaksanaan terapi psikoedukasi melalui musikuntuk menjadikan terapi psikoedukasi melalui musiksebagai salah satu upaya dalam mengatasi masalah self efficacy remaja berisiko

Instrumen yang sudah digunakan dalam penelitian ini hendaknya dapat digunakan sebagai alat ukur bagi remaja berisiko untuk masa mendatang.

Untuk penelitian yang akan datang hendaknya perlu dirancang intervensi atau terapi lainyang dapat meningkatkan self efficacy remaja berisiko.

\section{DAFTAR PUSTAKA}

Arsyam, S., \& Murtiani, M. (2017). Pola Asuh Orang Tua dengan Tingkat Depresi pada Remaja. Journal Islamic Nursing, 2(1), 17-20

BNN. (2016). Survei BNN dan Puslitkes UI,. https://bnn.go.id/remaja-indonesia-takada-waktu-untuk-narkoba/

Kartikasari, R., Yusep, I., \& Sriati, A. (2017). Pengaruh Terapi Psikoedukasi Keluarga terhadap Self Efficacy Keluarga dan Sosial Okupasi Klien Schizophrenia. Jurnal Keperawatan Padjadjaran, 5(2). https://doi.org/10.24198/jkp.v5i2.450

Kesuma, R. G., Pambudi, A. T., \& Aliyah, S. N. (2018). Kelompok Psikoedukasi sebagai Strategi Meningkatkan Self-Efficacy Pengambilan Keputusan Karier dan Adaptabilitas Karier Peserta Didik SMP di Kota Semarang. Prosiding Seminar Nasional: Strategi Pelayanan Bimbingan dan Konseling di Era Disrupsi, 2018, 242-247

KPAI. (2016). Data Kasus Perlindungan Anak Berdasarkan Lokasi Pengaduan dan Pemantauan Media Se-Indonesia Tahun 2011-2016. http://bankdata.kpai.go.id/tabulasi-data/data-kasus-se-indonesia/data-kasus perlindungan-anak-berdasarkan-lokasi-pengaduan-dan-pemantauan-mediaseindonesia-tahun-2011-2016

KPAI. (2018). Laporan Kinerja KPAI-2017. https://www.kpai.go.id/informasipublik/lakip/laporan-kinerja-kpai-tahun-2017

Kusumaryani, M. (2017). Ringkasan Studi Prioritaskan Kesehatan Reproduksi Remaja Untuk Menikmati Bonus Demografi. Lembaga Demografi FEB UI. http://ldfebui.org/wp-content/uploads/2017/08/BN-06-2017.pdf

Mendelson, T., \& Tandon, S. D. (2016). Prevention of Depression in Childhood and Adolescence. Child and Adolescent Psychiatric Clinics of North America, 2(2), 201-218. https://doi.org/10.1016/j.chc.2015.11.005 
Nogaj, A. A. (2020). Emotional Intelligence and Strategies for Coping with Stress among Music School Students in the Context of Visual Art and General Education Students. Journal of Research in Music Education, 68(1), 78-96. https://doi.org/10.1177/0022429420901513

Padila, P., Setiawati, S., Inayah, I., Mediani, H. S., \& Suryaningsih, C. (2020). Emosi dan Hubungan Antar Sebaya pada Anak Tunalaras Usia Sekolah antara Terapi Musik Klasik (Mozart) dan Murrotal (Surah Ar-Rahman). Jurnal Keperawatan Silampari, 3(2), 725-763. https://doi.org/https://doi.org/10.31539/jks.v3i2.1276

Situmorang, D. D. B. (2017a). Efektivitas Pemberian Layanan Intervensi Music Therapy untuk Mereduksi Academic Anxiety Mahasiswa terhadap Skripsi. JBKI (Jurnal Bimbingan Konseling Indonesia), $2(1), \quad 4$. https://doi.org/10.26737/jbki.v2i1.242

Situmorang, D. D. B. (2017b). Mahasiswa Mengalami Academic Anxiety terhadap Skripsi? Berikan Konseling Cognitive Behavior Therapy dengan Musik. Jurnal Bimbingan Dan Konseling Ar-Rahman, 3(2), 31-42. https://doi.org/http://dx.doi.org/10.31602/jbkr.v3i2.1161

Situmorang, D. D. B. (2018). Keefektifan Konseling Kelompok Cognitive Behavior Therapy (CBT) dengan Teknik Passive dan Active Music Therapy terhadap Academic Anxiety dan Self-Efficacy. Universitas Negeri Semarang

Situmorang, D. D. B., Wibowo, M. E., \& Mulawarman, M. (2018). Perbandingan Efektivitas Konseling Kelompok CBT dengan Passive Vs Active Music Therapy untuk Mereduksi Academic Anxiety. Journal of Psychological Science and Profession, 2(2), 143. https://doi.org/10.24198/jpsp.v2i2.17803 